\title{
The Dollar and Real Interest Rates
}

\section{Citation}

Campbell, John Y., and Richard H. Clarida. 1987. The dollar and real interest rates. CarnegieRochester Conference Series on Public Policy 27: 103-139.

\section{Published Version}

http://dx.doi.org/10.1016/0167-2231(87)90005-4

\section{Permanent link}

http://nrs.harvard.edu/urn-3:HUL.InstRepos:3221495

\section{Terms of Use}

This article was downloaded from Harvard University's DASH repository, and is made available under the terms and conditions applicable to Other Posted Material, as set forth at http:// nrs.harvard.edu/urn-3:HUL.InstRepos:dash.current.terms-of-use\#LAA

\section{Share Your Story}

The Harvard community has made this article openly available.

Please share how this access benefits you. Submit a story.

Accessibility 
NBER WORKING PAPER SERIES

THE DOLLAR AND REAL INTEREST RATES

John Y. Campbe 11

Richard H. Clarida

Working Paper No. 2151

NATIONAL BUREAU OF ECONOMIC RESEARCH 1050 Massachusetts Avenue

Cambridge, MA 02138

February 1987

Prepared for the Carnegie-Rochester Conference on Public Policy, November 21-22, 1986, Carnegie Mellon University, Pittsburgh, Pennsylvania. This paper was commissioned and the work completed before $\mathrm{Clarida}$ assumed his position as Senior Staff Economist at the CEA. The views expressed in this paper should not be interpreted as reflecting the views of members of the Council of Economic Advisers or their staff. We would like to thank John Montgomery, Robin Lumsdaine, and Pradeed Srivastava for the ir able research assistance, and John Huizinga, Rick Mishkin and members of the MIT macro lunch group for helpful comments. The support of the National Science Foundation, grants SES 85-11070 and SES 84-20227, is acknowledged with thanks. We are of course responsible for all errors. The research reported here is part of the NBER's research programs in Financial Markets and Monetary Economics and International Studies. Any opinions expressed are those of the authors and not those of the National Bureau of Economic Research. 
NBER Working Paper \#2151 February 1987

The Dollar and Real Interest Rates

\section{$\underline{\text { ABSTRACT }}$}

In this paper, we investigate the link between the real foreign exchange value of the dollar and real interest rates since 1979. We argue that it is important to consider the possibility that real exchange rate movements reflect movements of the long-run equilibrium exchange rate as well as real interest differentials. We use a state-space approach to estimate the importance of shifts in the long-run equilibrium exchange rate, the persistence of the ex ante short-term real interest differential, and the effect of this differential on the exchange rate. Using U.S., Canadian, British, German and Japanese data from October 1979 to March 1986, we find that movements in the dollar real exchange rate have been dominated by unanticipated shifts in the expected long-run real exchange rate. Ex ante real interest differentials have not been persistent or variable enough to account for a major part of exchange rate variation. We use Mussa's (1984) rational expectations model of the real exchange rate and the current account to interpret our results.

John Y. Campbell

NBER

1050 Massachusetts Avenue

Cambridge, MA 02138

(617) 868-3900
Richard H. Clarida

The Council of Economic Advisers

Old Executive Office Building

Washington, DC 20500

(202) 395-3114 


\section{The Dollar and Real Interest Rates}

$$
\text { by }
$$

John Y. Campbell and Richard H. Clarida

\section{Introduction}

The substantial, sustained real appreciation of the dollar during the first half of the $1980^{\prime}$ 's and its subsequent depreciation since February 1985 are perhaps the most debated and discussed macroeconomic events of this decade. According to one influential view (as put forth by Blinder (1986), Branson (1985), Frankel (1985), and Sachs (1985)), the strong dollar of 1980 through early 1985 was the result of a significant shift in the U.S. policy mix toward persistent structural budget deficits and a credible, anti-inflationary monetary stance on the part of the Federal Reserve. Other authors (Obstfeld (1985), Poole (1985), the Council of Economic Advisers $(1985,1986))$ have linked the real appreciation of the dollar in the years following the 1981-82 recession to the surprising surge in real business fixed investment spending. Still another hypothesis (which has been explored by Frankel (1985)) is that the rise and fall of the dollar resulted from a speculative bubble in the foreign exchange market.

The real appreciation of the dollar in 1980-1985 coincided with a marked increase in short and long term real interest rates, particularly in the U.S. but also abroad (Blanchard and Summers (1984)). This led to the view, especially popular in the financial press, that "the dollar is strong because U.S. real interest rates are high." of course, to the extent that a shift in monetary policy was responsible for high real 
interest rates in the U.S. relative to those elsewhere, theory would predict a real appreciation of the dollar - with overshooting - followed by a real depreciation to offset high U.S. real interest rates. However, the dollar consistently appreciated in real terms from 1980 through February 1985. This fact, along with the observation that the slowdown in U.S. money growth over the 1980-1984 period was in fact moderate compared with that experienced in Japan, Germany, and the United Kingdom, has directed research towards explanations of the sustained real appreciation of the dollar which emphasize real rather than purely monetary factors.

Since February 1985, the dollar has depreciated substantially in both nominal and real terms against the currencies of the other G5 countries. The extent of depreciation against the currencies of other major U.S. trading partners - Canada, the Latin American countries, and the NIC's in particular - has been less pronounced, especially in real terms. During this period, there has been a sustained increase in U.S. money growth, a decline in GNP growth, the announcement in September 1985 of an effort by the G5 central banks to bring down the value of the dollar, and Congressional deliberation of a major reform of the tax code. In addition, passage of the Gramm-Rudman legislation in December 1985 committed Congress and the President to a budgetary process which would achieve a balanced Federal budget by Fiscal 1991. Against this backdrop, both long and short term interest rates have declined sharply in the U.S. and abroad, as has the the slope of the U.S. term structure.

In this paper, we investigate the link between the real foreign exchange value of the dollar and real interest rates since 1979 . We ask 
how much movement in real exchange rates can be attributed to real interest differentials, and how much is due to shifts in the long-run equilibrium real exchange rate.

We begin in Section 2 by analyzing the responses of the real exchange rate, the real interest differential and the long-run equilibrium real exchange rate when there is a shock to autonomous expenditure on domestic goods. As discussed above, this type of shock - in private investment or perhaps government spending - is one possible explanation of the high dollar in the early 1980's. We show that under certain circumstances, a permanent positive shock to spending on domestic goods can lead to a higher real interest rate at home (a negative real interest differential) in the short run, and a real appreciation (a decrease in the real exchange rate, the relative price of imports) in both the short and long run. The shock also generates current account deficits in the short run. Our analysis is important for two reasons. First, it clarifies the way in which spending shocks might account for the experience of the early 1980 's. Secondly, the claim is sometimes made that an autonomous increase in spending which, in the short run, worsens the current account must of necessity lead to a long-run real depreciation which generates the trade surpluses required to service the accumulated stock of net foreign debt. Our analysis shows, contrary to this, that the long-run equilibrium exchange rate can move in the same direction as the current exchange rate when there is a spending shock.

In Section 3 we discuss the traditional methodology for identifying movements in the long-run equilibrium exchange rate. In general, the difference between the log level of the real exchange rate and its 
expected long-run value depends upon the expected sum of current and all future short-term real interest differentials as well as a risk premium. This relationship is of sufficient generality that it is virtually devoid of empirical content. In particular, in the absence of restrictions on the expected long-run equilibrium real exchange rate and the time series properties of the real interest differential and the risk premium, there is no simple link between the level of the real exchange rate and the ex ante real interest differential.

The traditional approach (taken by Frankel (1985), Shafer and Loopesko (1983) and Sachs (1985)) is to assume that the expectations hypothesis of the term-structure holds, and that the cross-currency risk premium is zero. These restrictions imply that the difference between the log of the real exchange rate and its expected long-run level is proportional to the ex ante long-term real interest rate differential. Of course this differential is unobservable, and must be constructed using the longterm nominal differential and a proxy for the expected long-term inflation differential.

The problem with this is that it is hard to measure expected long-term inflation rates. We provide evidence that widely cited estimates of the differential between the ex ante long-term real interest rate in the U.S. and the other G7 countries as of February 1985 (the month in which the real value of the dollar peaked) may substantially overstate the absolute value of the true real differential as of that date. If this is true, the estimates understate the extent of long-run equilibrium dollar appreciation.

In Section 4 we propose an alternative approach to the problem. We 
develop an econometric framework which can be used to estimate the effect of the ex ante short-term real interest differential on the exchange rate, and the extent to which real exchange rate changes reflect shifts in the expected long-run equilibrium real exchange rate. The framework also provides an estimate of the correlation between innovations in the ex ante real interest differential and the expected long-run exchange rate, and allows for the presence of a time varying risk premium.

Our approach may be described as follows. The ex ante short-term real interest differential is unobservable as is the expected long-run real exchange rate. However, the ex post short-term real differential and the current log level of the real exchange rate are observable. We assume that the ex ante short-term real differential is AR(1). This implies that the difference between the current log level of the real exchange rate and its expected long-run level is proportional to the ex ante short-term real interest differential. We also assume that the long-run real exchange rate follows a random walk.

With these assumptions, it is possible to estimate a state-space model in which two observable variables, the log level of the real exchange rate and the ex post short-term real interest differential, are an exact linear combination of the unobservable state variables, the ex ante real differential, the expected long-run real exchange rate, and the error in forecasting inflation differentials.

The advantage of such a tightly restricted system is that it provides efficient estimates of the minimum set of parameters required to estimate the extent to which fluctuations in the (observable) real exchange rate mirror fluctuations in the (unobservable) ex ante real interest 
differential as opposed to shifts in the (unobservable) expected long-run real exchange rate. By using the short-term real differential we avoid the problem of employing proxies for long-run inflation expectations. The parameter estimates take account of the sampling error associated with estimating the ex ante differential from the ex post differential, and allow for covariance between shifts in the expected long-run real exchange rate and innovations in the ex ante differential.

Our basic findings, presented in detail in section 5, are easily summarized: since 1980, movements in the dollar real exchange rate have been dominated by unanticipated shifts in the expected long-run dollar exchange rate. Ex ante real interest differentials have simply not been persistent enough, and their innovation variance simply not large enough, to account for a substantial fraction of the variation in the dollar real exchange rate over this period.

We also find that the covariance between innovations in real interest differentials and in the long run equilibrium exchange rate has been positive in the 1979-86 period. That is, shocks which have increased real interest rates in the U.S. relative to foreign countries have also appreciated the long-run equilibrium real exchange rate and the current real exchange rate. This is precisely the pattern that we model theoretically in Section 2 .

In Section 6 we relate our results to other recent empirical research on real exchange rates and interest rates, and we discuss current conjectures about the sources of the real dollar depreciation which has occurred since early 1985. 


\section{Autonomous Spending Shifts and the Long-Run Real Exchange Rate}

In the simple textbook Mundell-Flemming world, a permanent autonomous increase in spending on domestic goods results in a permanent decline in the relative price of imports (a permanent real appreciation) and a sustained current account deficit. Current account deficits which result from autonomous expenditure shifts redistribute wealth away from the deficit country to the rest of the world. While the Mundell-Flemming model ignores the effects of this wealth transfer, a number of recent models of current account and exchange rate dynamics imply that the decline in domestic wealth reduces domestic absorption relative to national product, induces a real depreciation with an accompanying real interest differential, and gradually eliminates the current account deficit (see Mussa (1984) for a survey and extension of the literature).

It is sometimes claimed that the deterioration of a country's net foreign asset position resulting from an autonomous increase in spending requires a long-run real depreciation which more than offsets the initial real appreciation. The reasoning behind this argument is straightforward: the exchange rate must depreciate in real terms relative to its initial equilibrium to generate the trade-balance surpluses necessary to service the interest payments on the economy's accumulated stock of net foreign debt. To evaluate this claim, we investigate the stationarystate properties of Mussa's (1984) rational expectations model of the current account and the real exchange rate.

Consider an open economy which produces a fixed quantity of a tradeable good (the domestic good), consumes the domestic as well as a foreign good, and trades a single real asset (denominated in foreign 
goods) with the rest of the world. The rate of return on this asset, $r$, is assumed constant and the net stock held by domestic residents, a, may be positive or negative. Foreign residents are willing to exchange foreign goods for real assets at the prevailing rate of return $r$, but their demand for domestic goods in exchange for foreign goods is less than perfectly elastic with respect to the relative price of foreign goods in terms of domestic goods, the real exchange rate. Let $q$ denote the logarithm of the real exchange rate.

Spending on domestic goods by domestic residents depends upon the real exchange rate, the desired level of total spending on both domestic and foreign goods by domestic residents, and an autonomous component of total domestic spending which is assumed to fall exclusively on domestic goods. The sum of the excess demands of domestic and foreign residents for domestic goods (in terms of foreign goods) is assumed to be given by

$$
\mathrm{h}=\mathrm{s}(\mathrm{y}-\mathrm{x})+\mathrm{q}+\mathrm{x}
$$

where $y$ is the excess of the desired level of total domestic spending on both domestic and foreign goods over the value of domestically produced goods (both measured in terms of foreign goods), $s$ is the marginal expenditure share of total desired domestic spending which falls on domestic goods, and $\mathrm{x}$ is an autonomous component of domestic spending which falls exclusively on domestic goods.

An increase in the excess of total desired domestic spending over the value of domestic production increases the excess demand for domestic goods by the share of such spending, $s$, which falls on domestic goods in the absence of exchange rate changes. A rise in $q$ represents a real exchange rate depreciation (an increase in the relative price of imports) 
which shifts both domestic and foreign spending to domestic goods. Finally, an increase in autonomous spending on domestic goods, $\mathrm{x}$, leaves the difference $(y-x)$ unaffected (because desired total spending increases one for one with autonomous spending) but increases the excess demand for domestic goods.

In equilibrium, the sum of the excess demands of domestic and foreign residents for domestic production must equal zero. Setting $h=0$ in equation (1) and rearranging terms we obtain the following condition for equilibrium in the market for domestic goods:

$$
y=-v(q+(1-s) x)
$$

where $v=1 / s$. Equation (2) states that, for any given level of autonomous spending, an increase in the desired excess of total domestic spending over the value of domestic product requires a real appreciation of the domestic currency to restore equilibrium in the market for domestic goods. Furthermore, as shown in Mussa (1984, p.29), given the value of $y$, equilibrium in the domestic goods market implies that the domestic excess demand for foreign goods is zero.

The determinants of desired total spending by domestic residents are assumed to be the domestic real interest rate (relative to the world real interest rate), the stock of net foreign assets, the difference between net foreign assets and their target level, and an autonomous component. Specifically, desired saving - the difference between national income (including interest income) and total desired spending - is assumed to be given by

$$
r a-y=(R-r)+u(A-a)-x
$$

where $R$ is the domestic real interest rate, $A$ is the target level of 
assets, and $u$ is a partial adjustment parameter such that $0<u<1$. An increase in the domestic real interest rate is assumed to increase desired saving and thus to depress the excess of desired total spending over the value of national product. Similarly, the larger is the difference between actual and target assets, the smaller is desired total spending and the larger is desired saving. Finally, an autonomous increase in desired spending, $x$, represents an autonomous decrease in desired saving and, if $\mathrm{x}$ is permanent, an autonomous decrease in the target level of assets.

The domestic real interest rate depends on the world interest rate, $r$, and the expected rate of change of the relative price of foreign goods $E[D(q)]:$

$$
R=r+s E[D(q)]
$$

where $D$ is the forward difference operator. If the relative price of foreign goods in terms of domestic goods is expected to increase, then an asset that pays a rate of return $r$ in foreign goods has a rate of return $R$ in terms of the domestic consumption basket which exceeds $r$ by $E[D(q)]$ weighted by the marginal expenditure share s devoted to domestic goods. As a matter of accounting, the current account surplus corresponds to the rate of accumulation of net foreign assets, and is equal to the excess of national income (including interest income) over total spending by domestic residents. Using the equilibrium condition (2) for the market for domestic product, the accumualtion of net foreign assets can be written

$$
D(A)=v(q+(1-s) x))+r a .
$$

The current account surplus must also, in equilibrium, equal desired 
saving. Substituting (4) into (3) and equating to (5), we obtain

$$
v((1-s) x+q)+r a-s E[D(q)]+u(A-a)-x .
$$

Equations (5) and (6) represent a system of forward looking difference equations which jointly determine the time paths of the real exchange rate, $q$, and net foreign assets, a, conditional on the initial stock of foreign assets and the expected future path of autonomous spending. The general solution for this model is provided by Mussa, and is investigated further by Mussa and Frenkel (1985). For the special case in which shifts in autonomous spending are expected to be permanent (so that $x(t)$ $\left.=E_{t}[x(t+j)]=x\right)$ a number of concrete results are obtained which we now summarize.

The first and most basic set of results is that a permanent, autonomous increase in spending on domestic goods induces a jump real appreciation, an increase in real interest rates at home relative to those abroad (a fall in the real interest differential), and a current account deficit. The increase in home real interest rates dampens, but does not reverse, the excess of total spending by domestic residents over national income which is created by the autonomous spending increase. Similarly, the real appreciation shifts a portion of the excess domestic spending toward foreign goods as domestic and foreign residents find foreign substitutes relatively less expensive.

In subsequent periods, the excess of total spending by domestic residents over national income (the current account deficit) narrows as the wealth effect of a declining stock of net foreign assets reduces total domestic spending. As spending falls, the home currency depreciates; indeed, it is the expectation of this subsequent 
depreciation which induces the initially high level of domestic real interest rates. A noteworthy feature of the model's rational expectations equilibrium is that the ex ante real interest differential follows an AR(1) process, so that the difference between the current log level of the real exchange rate and its expected long-run equilibrium value is always proportional to the current one-period ex ante real interest differential. We examine an empirical specification of this type in Section 4. Unfortunately, as is so often the case in empirical macroeconomics, this result does not generalize to more general specifications for the forcing variables, in this case autonomous spending.

The rational expectations equilibrium paths for the real exchange rate, the real interest differential, and the current account converge to a stationary state in which the real interest differential is zero, the current account is in balance, and the real exchange rate is constant. From equation (3) we see that the stationary-state level of net foreign assets is given by $a=A-x / u$ which we shall assume, without any loss of generality, is negative. In the stationary state, the excess of national product over desired spending must be sufficient to service the interest on the accumulated stock of foreign debt. Does this in itself imply that the home currency must depreciate in the long run by more than the initial appreciation? The stationary-state condition for a balanced current account is obtained by substituting $a=A-x / u$ in equation (5) and setting the right-hand-side to zero:

$$
-r(A-x / u)=v((1-s) x+q) .
$$

A bit of algebra reveals that the necessary and sufficient condition for 
a long-run real appreciation in response to a permanent increase in autonomous spending is

$$
1 / s>(1+r / u) \text {. }
$$

Recall that $u$ is the partial adjustment parameter and that $r$ is the world real rate of interest. For plausible parameter values, the ratio $r / u$ is most likely less than $1 / 4$. Thus, a value of $s<.8$ would insure that the long-run real exchange rate would appreciate in response to a permanent increase in autonomous spending.

Equation ( 8 ) nicely summarizes the two counteracting influences of a permanent increase in autonomous spending on the long-run real exchange rate. Autonomous spending which falls on domestic goods requires a real appreciation which shifts spending away from domestic goods which are in excess demand. However, permanent increases in autonomous spending can reverse the country's net foreign asset position to that of a substantial net debtor. The interest on this debt must be met by an export surplus which, ceterus paribus, requires a real depreciation which shifts spending towards domestic goods. Thus, the higher the world real interest rate and the smaller the rate at which saving adjusts, the larger is foreign debt and debt service in the stationary-state and the more likely it is that the real exchange rate must depreciate. However, so long as the ratio $1 / s$ exceeds $1+r / u$, this effect is outweighed and the long-run real exchange rate appreciates despite a potentially substantial accumulation of foreign debt in the stationary state.

For example, suppose that in the initial stationary state autonomous spending is zero, net foreign assets are positive, and that $u=.20, r=$ .04 , and $s=.80$. Consider now a shift in autonomous spending equal to 
initial foreign assets. From equations (7) and (8), we see that in the new stationary state, the long-run equilibrium exchange rate appreciates because $(1 / .80)>1+(.04 / .20)$. Yet, the stock of foreign debt in the new stationary state is four times the stock of foreign assets in the original stationary state ( since by assumption $\mathrm{x}=\mathrm{A}$ and net foreign assets in the new stationary state are given by $A-x / u)$.

The above model, while simple, usefully illustrates several key properties of the real exchange rate. First, the current level of the real exchange rate depends upon the expected level of the long-run real exchange rate which is consistent with a balanced current account. Second, autonomous spending disturbances will be expected to shift the long-run real exchange rate. Third, if autonomous spending falls on domestic goods, there is a presumption that the real exchange rate will initially appreciate even if in the long run it must depreciate. Fourth, the fact that the current account deficits associated with an autonomous spending increase can result in a potentially large stock of foreign debt does not necessarily imply that the long run real exchange rate must depreciate relative to its initial equilibrium.

In sum, autonomous expenditure shifts will in general change the expected long-run level of the real exchange rate. Shifts in autononmous expenditure which are perceived to be permanent and which fall on domestic goods will induce a real appreciation on impact, and may induce a long-run real appreciation even if the current account adjustment mechanism entails the accumulation of a substantial stock of foreign debt. 


\section{Empirical Evidence on the Long Run Real Exchange Rate}

One influential view of exchange rate behavior in the 1980's stresses the importance of tight monetary policy during 1980-1982. This view uses Dornbusch's (1976) overshooting model with sluggish price adjustment to account for both the real dollar appreciation and high U.S. real interest rates in the early $1980^{\prime} s$. It gives no important role to shifts in the long-run equilibrium real exchange rate. Sachs (1985) and Franke1 (1985) present empirical evidence supporting the notion that very little of the real appreciation of the dollar between 1980 and early 1985 was due to a shift in the expected long-run real exchange rate. Their approach is to use proxies for ex ante real interest differentials on long-term bonds to make inferences about the expected cumulative real appreciation of the dollar over the life of the bonds. If uncovered interest parity holds, then the market's expectation of the cumulative real appreciation of the dollar against a particular foreign currency is just $n D_{n t}={ }^{n} E_{t}\left(r_{f, n, t}-r_{u s, n, t}\right)$, where $n$ is the number of years until the bonds mature and $r_{j, n}$ is the ex post real yield to maturity on $n$ year bonds denominated in the currency of country $j$. In practice, the expected real yield differential $D_{n t}$ is unobservable, and a proxy for the average expected annual inflation differential over the $n$ year interval must be subtracted from the nominal yield differential to obtain a proxy for the ex ante real yield differential.

Table 1 presents Frankel's (1985) estimates of the ex ante real interest rate differential as of February 1985 on 10 year government bonds in the U.S. and a weighted average of the other G7 countries. Three proxies for the expected annual average inflation rate over the 
next 10 years are used, one year lagged inflation, three year distributed lagged inflation, and a DRI forecast of inflation. As of February 1985, nominal yields in the U.S. were 237 basis points higher than the weighted average of foreign yields, so the nominal yield differential stood at -237 basis points; the estimated real differential ranges from -270 to - 346 basis points. Assuming that the market expected the real exchange rate to reach long-run equilibrium within 10 years, the real value of the dollar relative to the other G7 countries as of February 1985 was, according to Frankel's estimates, some 24 to 358 above its long-run real equilibrium. Frankel concludes that, "compared with the 33 percent logarithmic real appreciation that the weighted dollar has experienced relative to its 1973-1979 average, . . . most of the real appreciation is attributable to an increase in the real interest differential. Relatively little seems attributable to a change in the long-run equilibrium exchange rate (Franke1 (1985), p.202)." Using a somewhat different proxy - a two-year centered moving average of actual inflation rates - for expected inflation over a ten year period, Sachs (1985) reaches much the same conclusion with regards to the the real overvaluation of the dollar relative to the mark as of the end of 1984 .

These calculations are especially sensitive to errors in the measurement of the expected annual average inflation rate over the life of the bonds. To assess the potential magnitude of this measurement error, we recompute Frankel's estimate of the real long-term interest differential as of February 1985 using Richard Hoey's survey of ten year U.S. inflation expectations of financial market participants as of that date. The results are presented in the bottom row of Table 1 . According to 
Hoey's survey, U.S. financial market participants were expecting an average annual inflation rate of 5.498 as February 1985. This is 1.33 percentage points higher than Frankel's estimate of expected U.S. inflation using the DRI forecast and 1.95 percantage points higher than his estimate using one-year lagged inflation. The implied ex ante real yield on 10 year U.S. government bonds using the Hoey survey results is 6.218 compared with Frankel's estimates of between 7.548 and 8.168 . How much of a difference does this make in calculating the overvaluation of the dollar as of February 1985? A lower bound on the extent of overvaluation can be obtained by subtracting Frankel's highest estimate of the weighted average foreign real 10 year yield, 5.258 , from the U.S. rate implied by Hoey's estimate and multiplying by 10 . The result is an estimated overvaluation of only 9.68 as of February 1985.

Thus, depending on the measure of inflationary expectations used, the dollar was overvalued in real terms as of February 1985 by less than 108 or more than 308 . The point of these calculations is not to criticize any particular choice of proxies for long-term inflationary expectations, but just to illustrate how sensitive any computation based upon expected long-term real interest rates is to the proxy chosen. Because of this sensitivity, no clear consensus has emerged on the extent of dollar overvaluation in early 1985. For example, Obstfeld argued in April 1985 that

At present, long-term nominal interest differentials between the U.S. and West Germany are roughly 200 basis points above short-term differentials. Under the expectations theory, this implies an expected rise in the U.S. - West German short-term real interest differential, an expected future increase in relative U.S. inflation, or some of each. Given the probable future evolution of fiscal positions within the OECD, I find the expected 
inflation explanation of the current international term structure most plausible. While the real value of the dollar should be expected to fall, I am not convinced that markets expect it to fall as far as its 1977 level (Obstfeld comment on Sachs (1985)).

clearly there is much to be gained from an alternative way to estimate the long-run equilibrium exchange rate.

\section{An Econometric Framework}

In this section we develop an econometric framework which can be used to estimate and interpret (i) the contemporaneous correlation between the real exchange rate and the ex ante short-term real interest differential; and (ii) the extent to which fluctuations in the real exchange rate reflect shifts in the expected long-run real exchange rate. The framework also provides an estimate of the correlation between innovations in the long-run real exchange rate and in the ex ante shortterm real interest differential.

We begin with the following basic relationship:

$$
q_{t}=E_{t}\left[q_{t+1}\right]+E_{t}\left[d_{t}\right]+k_{t}
$$

Here $q_{t}$ is the natural $\log$ of the real exchange rate at the start of period $t$, defined as the nominal exchange rate divided by the ratio of the U.S. and foreign price levels. When the dollar appreciates in real terms, $q_{t}$ falls. $d_{t}=r_{f, t}-r_{u s, t}$ is the ex post short-term real interest differential, the ex post one-period real interest rate realized on foreign assets in period $t$, less the ex post one-period real rate on U.S. assets. Finally, $k_{t}$ is a risk premium which separates the expected rate of real appreciation of the dollar from the ex ante real interest 
differential. When $k_{t}=0$, equation (9) follows immediately from the logarithmic approximation to the uncovered interest parity condition (Cumby and Obstfeld (1984)).

Solving equation (9) forward, we obtain

$$
q_{t}=w_{t}+\sum_{j=0}^{\infty} E_{t}\left[d_{t+j}\right]+\sum_{j=0}^{\infty} E_{t}\left[k_{t+j}\right],
$$

where $w_{t}$ is the limit as $i$ approaches infinity of $E_{t}\left[q_{t+i}\right]$, the expectation at time $t$ of the long-run $\log$ real exchange rate. We assume that this limit exists (which requires, for example, that ex post real interest differentials follow a stationary stochastic process with mean zero). Equation (10) expresses the difference between the current and long-run log level of the real exchange rate as the undiscounted sum of current and expected future one-period real interest differentials plus the undiscounted sum of current and expected future risk premia.

Absent restrictions on the time series properties of $w_{t}, E_{t}\left[d_{t}\right]$, and $k_{t}$, equation (10) is virtually devoid of empirical content. One approach employed by Shafer and Loopesko (1983) and Sachs (1985) is to assume that $w_{t}$ is constant, $k_{t}-0$ for all $t$, and that a proxy for the ex ante longterm real interest differential, $D_{n t}$, exactly incorporates the undiscounted sum of current and future short-term real interest differentials. Under these assumptions, the following regression should have an $\mathrm{R}^{2}$ of 1 :

$$
q_{t}=w+n D_{n t}
$$

As discussed in detail in the previous two sections, it is quite likely that any proxies for expected inflation used to construct the long-term 
real interest differentials are subject to measurement error and perhaps even bias. Furthermore, on both theoretical and empirical grounds, it is desirable to allow for shifts in the expected long-run real exchange rate. If fluctuations in $w_{t}$ are correlated with the real differential, then the regression given by equation (11) cannot be used to interpret the correlation between the the real exchange rate and the real interest differential.

Our approach is to parameterize the dynamics of the variables in (10), without assuming that they are observable. With parsimony in mind, we impose the following restrictions on the unobservables $w_{t}, E_{t}\left[d_{t}\right]$, and the forecast error $e_{t}=d_{t}-E_{t}\left[d_{t}\right]$ :

$$
\begin{aligned}
E_{t}\left[d_{t}\right]=\rho E_{t-1}\left[d_{t-1}\right]+v_{t} \\
v_{t}=\lambda e_{t-1}+u_{1 t} \\
e_{t}=u_{2 t} \\
w_{t}=w_{t-1}+u_{3 t} \\
E\left[u_{j t} u_{i, t-k}\right]=0 ; i, j=1,2,3 ; k>1
\end{aligned}
$$

Equation (12) restricts the ex ante one-period real differential to be a zero mean $\operatorname{AR}(1)$ process with parameter $\rho$. Equation (13) expresses the innovation to this process from the beginning of period t-1 to the beginning of period $t$ as the sum of two terms, a multiple $\lambda$ of the inflation surprise realized in period $t-1$, and an independent error $u_{1 t}$. Equation (14) is just the rational expectations restriction that the inflation surprise (the difference between the ex post and ex ante real interest differential) is white noise. Equation (15) imposes the restriction that changes in the expected long-run real exchange rate are 
unforecastable. The innovation in $w_{t}$ could in general depend on $e_{t-1}$, as the innovation in $E_{t}\left[d_{t}\right]$ does, without violating this restriction (since $e_{t-1}$ is not known until the start of period $t$ ). However for simplicity we exclude such a correlation. (When we estimated a model leaving this correlation free, we found little increase in likelihood, and qualitatively similar estimates to those reported.) Finally, equation (16) states that the vector $\left[u_{1 t} u_{2 t} u_{3 t}\right]^{\prime}$ is white noise.

It should be said at the outset that the motivation for the AR(1) specification for the ex ante real interest differential is its empirical tractability. First, the AR(1) specification implies that the ex post real interest differential is an $\operatorname{ARMA}(1,1)$ process. The parameter $\rho$ is identified from the autocorrelations of the ex post differential alone (it is the rate at which higher-order autocorrelations decay). Second, the $\mathrm{AR}(1)$ specification implies that, in the absence of a risk premium

$$
q_{t}=(1 /(1-p)) E_{t}\left[d_{t}\right]+w_{t}
$$

That is, the observable real exchange rate is a simple linear combination of the unobservable ex ante real interest differential and the unobservable expected long-run real exchange rate. The more persistent is the $A R(1)$ process for the ex ante differential, the bigger the effect of the differential on the real exchange rate.

The AR(1) specification for the real interest differential can also be motivated theoretically. In a world in which permanent, nominal shocks are predominant, Dornbusch's overshooting analysis implies the relationship given in equation (17). Furthermore, as shown in Section 2, permanent real shocks can lead to the same linear relationship between 
the real exchange rate and the short-term real interest differential. However, if real shocks are predominant, shifts in the expected long run real exchange rate will also account for fluctuations in $q_{t}$.

With this background, consider the following state-space model comprised of two measurement equations

$$
\left[\begin{array}{c}
q_{t} \\
d_{t}
\end{array}\right]=\left[\begin{array}{ccc}
1 /(1-p) & 0 & 1 \\
1 & 1 & 0
\end{array}\right]\left[\begin{array}{c}
E_{t}\left[d_{t}\right] \\
e_{t} \\
w_{t}
\end{array}\right]
$$

and three transition equations

$$
\left[\begin{array}{c}
E_{t}\left[d_{t}\right] \\
e_{t} \\
w_{t}
\end{array}\right]=\left[\begin{array}{lll}
\rho & \lambda & 0 \\
0 & 0 & 0 \\
0 & 0 & 1
\end{array}\right]\left[\begin{array}{c}
E_{t-1}\left[d_{t-1}\right] \\
e_{t-1} \\
w_{t-1}
\end{array}\right]+\left[\begin{array}{c}
u_{1 t} \\
u_{2 t} \\
u_{3 t}
\end{array}\right] .
$$

The measurement equations express the vector of two observable variables, the real exchange rate and the ex post real interest differential, as a linear transformation of the vector of three unobservable variables, the ex ante real interest differential, the error in forecasting inflation differentials, and the expected long-run real exchange rate. The transition equations provide the 1 aw of motion for the vector of unobservable variables. As discussed above, the vector of disturbances to the transition equations is assumed to be serially uncorrelated. The three errors have standard deviations $\sigma_{1}, \sigma_{2}$ and $\sigma_{3}$. The contemporaneous covariances $\sigma_{12}$ and $\sigma_{23}$ are zero by the property of rational forecast errors. $\sigma_{13}$ is the contemporaneous covariance between innovations in the 
expected long-run real exchange rate and innovations, unrelated to inflation surprises, in the ex ante real interest differential; it is left unrestricted.

The method of Kalman filtering can be used to estimate the parameters of the state-space model. In the absence of a risk premium, there are only two free parameters in the measurement and transition matrices, $\rho$ and $\lambda$. There are four free parameters in the variance-covariance matrix of the transition equation innovations, the three variances and the covariance $\sigma_{13}$.

A number of empirical studies have uncovered a time-varying risk premium in the foreign exchange market (see Cumby (1985) for a useful survey and extension of the literature; see Campbell and Clarida (1987) for a recent investigation of risk premia in Euromarket term structures). Within the context of our state-space framework, it is straightforward to introduce an unobservable time-varying risk premium of the following form:

$$
k_{t}=k E_{t}\left[d_{t}\right]
$$

Equation (18) says that the risk premium, which separates the expected rate of real appreciation from the real interest differential in favor of foreign assets, is proportional to the ex ante real differential. As such, it makes no statement about causality, but is merely a (very tight) restriction on the covariance between two endogenous, unobservable variables. Note that in the presence of a risk premium, the ex ante real interest differential is a biased predictor of the expected rate of real depreciation. Substituting (18) into (11), 


$$
q_{t}-E_{t}\left[q_{t+1}\right]=\alpha E_{t}\left[d_{t}\right]
$$

where $\alpha=1+k$.

By assuming that the risk premium is perfectly correlated with the ex ante real interest differential, we maintain the tractability of our approach while allowing the real interest differential to be a biased predictor of the expected rate of change of the real exchange rate. In particular, maintaining our restriction that the real interest differential is $\operatorname{AR}(1)$, equation (19) implies

$$
q_{t}=(\alpha /(1-\rho)) E_{t}\left[d_{t}\right]+w_{t} .
$$

The requisite modification to the measurement equation is apparent.

\section{Data and Empirical Results}

Data on one month Eurodeposit rates and spot exchange rates against the dollar were obtained for the U.S., Canada, the United Kingdom, Germany, and Japan from the Harris Bank tape. Consumer price indexes for these countries were obtained from the IFS tape. The sample period studied was November 1979 through March 1986. Exchange rates and interest rates were sampled on the last Friday of each month.

Real exchange rates were constructed as

$$
q_{t}=\ln \left(s_{t}\right) p_{f t} / p_{u s, t}
$$

where $s_{t}$ is the nominal exchange rate in units of foreign currency per dollar and $p_{f t} / p_{u s, t}$ is the ratio of foreign to U.S. CPI's. Ex post real interest differentials were constructed by subtracting the actual inflation differential (as measured by logarithmic changes in the country 
CPI's) over the following month from nominal one-month interest differential as of the last Friday of the preceding month. All results are reported in units of percent per month at an annualized rate.

Table 2 displays some summary statistics for our data over the period 1979:10-1986:3. The first four columns describe the Canadian, British, German and Japanese data respectively; the last column describes an average formed using 1980 trade weights (Canada 46.35\%, United Kingdom 12.438, Germany 12.698 and Japan 28.538 ).

The first two rows of Table 2 give the sample means and standard deviations of real exchange rate changes over the period. The sample means are negative, corresponding to real dollar appreciation, for all countries except Japan. The standard deviation for Canada is about $15 \%$ per month at an annualized rate, while for the other countries it exceeds 408.

The next two rows of the table give the same statistics for ex post real interest differentials. Sample means are negative for all countries, indicating that real interest rates were higher on average in the U.S. than abroad. Sample standard deviations range from 38 to 88 . These statistics emphasize that real exchange rate changes have been much more volatile than even ex post real interest differentials. A fortiori, they have been much more volatile than ex ante differentials. If real interest rate movements are to explain exchange rates, they must be highly persistent so that they have a magnified effect on the exchange rate (equation (17)), or there must be a very large risk premium effect (equation (20)).

At the bottom of Table 2, the first six autocorrelations of the ex 
post real interest differential are reported. These were computed assuming that the true mean of the real interest differential is zero (as discussed in the previous section, this is an implication of our exchange rate model and is also assumed when we estimate our state-space representation). Similar but slightly smaller numbers are obtained when one assumes that the sample mean differential is the true mean.

The largest autocorrelations occur for the German data. These autocorrelations die off smoothly so that the German ex post real interest differential looks much like an AR(1) process with coefficient 0.5 or 0.6 . This is striking since we model the ex ante differential as an $\operatorname{AR}(1)$ process so we expect to find more complex $\operatorname{ARMA}(1,1)$ behavior of the ex post differential. The autocorrelations are smaller for the other countries, starting at 0.25 for the U.K., 0.17 for Canada and 0.03 for Japan. They also have a less regular pattern.

In Tables $3-7$ we estimate the state space model described in the previous section, for each currency and the trade-weighted average. In each table we report results for a model assuming uncovered interest parity, and for the linear risk premium model of equations (18)-(20). We report the coefficients $\alpha, \rho$ and $\lambda$ with asymptotic standard errors, the standard deviations $\sigma_{1}, \sigma_{2}$ and $\sigma_{3}$ of the three error terms, and the correlation $\sigma_{13} / \sigma_{1} \sigma_{3}$. We also report some implications of these numbers: the fractions of the variance of the ex post real interest differential which are due to the variance of the ex ante differential and the variance of the inflation forecast error; the fractions of the innovation variance of the real exchange rate which are due to the innovation variance of the ex ante differential, the innovation variance of the 
long-run equilibrium real exchange rate and the innovation covariance between these variables; the correlation between real exchange rate innovations and innovations in the ex ante differential and the long-run equilibrium exchange rate; and finally, the correlation between innovations in the ex ante differential and innovations in the long-run equilibrium exchange rate.

The most striking feature of the results, which is robust across currencies and the presence of a linear risk premium, is how little of the variance of real exchange rate innovations is accounted for by innovations in the ex ante real interest differential. When uncovered interest parity is assumed, the estimates of the share of the ex ante differential in real exchange rate innovation variance are particularly small: they never exceed 98, while the long-run equilibrium exchange rate accounts for at least 798 and the covariance between components accounts for the rest of the variance.

In the linear risk premium model, the ex ante differential plays a somewhat larger role because the coefficient $\alpha$ is estimated larger than one in absolute value for all countries except Japan. Thus the risk premium amplifies the effect of the differential on the exchange rate. Even in the risk premium model, however, the largest share of the ex ante differential in real exchange rate innovation variance is 428 for the trade-weighted average. The estimates for individual currencies are all less than 278 .

The reason why we obtain these results is that we do not estimate enough persistence in the ex ante real interest differential to overcome the low standard deviation of the differential relative to the change in 
the exchange rate. Our estimates of $\rho$ range from 0.35 to 0.81 , and higher estimates tend to be associated with a smaller share of the ex ante differential in the variance of the ex post differential. (The ex ante differential accounts for less than 508 of the variance of the ex post differential except in Germany, where as noted above an AR(1) model rather than an ARMA $(1,1)$ model fits the ex post differential quite we11).

A second striking feature of our results is that the correlation between innovations in the long-run equilibrium real exchange rate and innovations in the ex ante real interest differential is almost always estimated to be positive. The one exception to this statement is the uncovered interest parity model for Germany, which has a tiny negative correlation of -0.04 . The positive correlation implies that shocks that have caused the expected long-run real exchange rate to appreciate have also increased real interest rates in the U.S. relative to those abroad. As we showed in Section 2, this pattern could result from permanent shocks to the demand for domestic goods.

In the uncovered interest parity models, a positive shock to the ex ante real interest differential raises the real exchange rate. In these models, therefore, the correlation between shocks to the long-run exchange rate and the real interest differential increases the variance of real exchange rate innovations.

In the linear risk premium models, on the other hand, the coefficient $\alpha$ is estimated to be negative for all currencies except the Canadian dollar and the Japanese yen. A negative $\alpha$ corresponds to a negative coefficient $k$, of absolute magnitude greater than one, in equation (18). In words, the ex ante real interest differential and the risk premium 
move inversely, and the risk premium has a larger variance. This is consistent with Fama's (1984) findings on the relationship between the nominal forward premium and the risk premium. When $\alpha$ is negative, a positive shock to the real differential causes the real exchange rate to fall, so the correlation between shocks to the long-run exchange rate and the differential reduces the variance of real exchange rate innovations. However the real exchange rate still moves in the same direction as the long-run equilibrium exchange rate in all the models we estimate.

Our approach relies on the assumption that the stochastic processes driving interest rates and exchange rates are stable through time. However changes in monetary and fiscal policies will in general alter these processes. Clarida and Friedman (1984) have documented a shift in the process for nominal U.S. Treasury bill rates after October 1979 , while Huizinga and Mishkin (1985) have isolated changes in the real interest rate process in the U.S. in October 1979 and October 1982. Our sample period starts in October 1979 , so the shift at that date does not contaminate our results. The October 1982 change is potentially more of a problem, but when we estimate our model for the trade-weighted average data in the post-October 1982 period, we find similar results to those reported in the tables. The uncovered interest parity model attributes over 958 of the variance of real exchange rate innovations to innovations in the long-run equilibrium rate. In the linear risk premium model, the innovations in the real interest differential and the long-run equilibrium rate are estimated to be almost perfectly correlated.

It is well known that real exchange rate changes are largely unpredictable (Cumby and Obstfeld (1984)), and a skeptic may argue that 
we have stacked the deck in favor of finding little explanatory power for the ex ante real interest differential by assuming that the expected long-run real exchange rate is a random walk. This is not the case: observations on the ex post real interest differential, along with our restrictions on the time series properties of the ex ante real differential, provide independent information on the persistence and variability of ex ante real interest differentials (Fama and Gibbons (1982)). The Kalman filtering procedure efficiently incorporates this information in estimating the parameters of the state-space model (Hamilton (1985)). We conclude that over the last seven years, ex ante real interest differentials have simply not been persistent enough, and their innovation variance just not large enough to account for much of the fluctuation in the dollar's real exchange rate.

\section{Assessments and Conclusions}

Although the methodologies and interpretations differ somewhat, our findings are consistent with recent work by several authors. For example, Meese and Rogoff (1985) use an instrumental variables procedure to estimate an unrestricted version of equation (11) in difference form. They conclude that changes in short-term real interest differentials are not particularly successful in accounting for changes in real exchange rates.

Our findings are also consistent with Mark's (1986) results on the cointegration of bilateral nominal exchange rates and relative national price levels. Mark shows that if departures from relative purchasing power parity are transitory, then the log of the nominal exchange rate 
and the $\log$ of the ratio of the corresponding national price levels are cointegrated. In other words, they share a common stochastic trend so that fluctuations in the real exchange rate do not represent shifts in the long-run real exchange rate. Using monthly data for the period June 1973 through June 1985, Mark finds no evidence of cointegration between seven bilateral dollar exchange rates and relative national price levels. He concludes that his evidence is consistent with the hypothesis that permanent real shocks have accounted for much of the variability in real exchange rates.

Our findings are also in accord with those reported by Huizinga (1987) in this volume. In a decomposition of real exchange rate movements into permanent and transitory components, Huizinga finds that the permanent component accounts for between 528 and $77 \%$ of the variance of the actual change in the real exchange rate for the bilateral exchange rates studied in this paper. While these estimates are somewhat lower than those reported in this paper (because Huizinga does not attempt to identify the transitory component with real interest differentials as we do), the results of these two papers, when taken together, provide solid evidence that fluctuations in real exchange rates in recent years have been dominated by shifts in the expected long-run real exchange rate.

Our results have some important implications for the analysis of economic policy. A first set of implications concerns the decline of the real foreign exchange value of the dollar during this decade. A second set of implications concerns the much greater volatility of real exchange rates since the collapse of the Bretton Woods system in the early 1970's. If one accepts that much of the real appreciation of the dollar during 
the first half of this decade was perceived as permanent by the foreign exchange markets, it follows that the dollar's real depreciation over the last two years has been largely unexpected. (In fact the depreciation has been rapid enough to surprise even someone who believed that the dollar was substantially overvalued in early 1985; the estimates reported by Frankel (1985) and Sachs (1985), for example, implied a gradual seven to ten year real depreciation of the dollar at a rate of roughly three percent per year.) Explanations of the depreciation (which continues as of this writing) must therefore focus on previously unanticipated shifts in policy and economic performance which have occurred over this period. Three major shifts in U.S. policy have occurred over the last two years. The first is a much more rapid expansion of monetary aggregates by the Federal Reserve since early 1985. The second is the passage of the Gramm-Rudman-Hollings deficit reduction legislation in late 1985. The third is the enactment of the Tax Reform Act of 1986. Each one of these policy changes has been cited as a source of the dollar's real depreciation. We now consider each in turn.

The shift in U.S. monetary policy since early 1985 is often cited as the principal source of the dollar's real depreciation over the last two years, especially given its conjunction with the slowdown in real GNP growth since the second quarter of 1984. According to the monetary-asset market approach to exchange rate determination, a shift to more rapid growth of the money supply relative to money demand would be expected to induce a nominal and, in the presence of sluggish price level adjustment, a real depreciation of the currency. The mechanism through which this would occur is a shift in inflationary expectations. Especially in light 
of the association of the "weak" dollar during the late 1970s with inflationary monetary policy, and the association of real appreciation with disinflationary monetary policy during the early 1980s, the appeal of this explanation is obvious.

However, this explanation of the dollar's real depreciation over the last two years suffers from an important shortcoming: apart from the depreciation of the dollar itself, there is little evidence that the financial markets expect a resurgence in U.S. inflation. The velocity of money has declined dramatically in tandem with the surge in money growth. A substantial increase in money demand relative to income is not the outcome which would be expected if inflation were anticipated to accelerate significantly in the U.S. as a result of the monetary policy currently being pursued. Furthermore, Hoey's survey results indicate that long-term inflation expectations have declined steadily over the last two years, albeit at a somewhat slower pace than the fall in longterm U.S. interest rates and the slope of the term structure. Indeed, as of November of 1986 , the average inflation rate expected over the next ten years by the respondents to Hoey's survey fell below 5 for for first time since the survey began in 1978. In sum, while a sustained increase in money growth would, on the basis of both theoretical research and historical experience, be expected to result in a real depreciation of the dollar, the behavior of velocity, long-term interest rates, and surveys of long-term inflation expectations cast doubt on this as the sole explanation of the dollar's real depreciation since early 1985.

The link between budget deficits and the real exchange rate is perhaps the most disputed policy question of the decade. In 1983 and 1984, the 
federal government ran record peacetime budget deficits and the dollar appreciated in real terms. In 1985 and 1986, the budget deficits exceeded those recorded in 1983 and 1984 and the dollar depreciated in real terms back to its 1982 level. Of course, the exchange rate is an asset price which reflects not only current, but prospective, budget deficits as well as the means by which they are to be financed. We have already discussed the evidence against the view that the real depreciation of the dollar reflects the expectation of a resurgence in U.S. inflation resulting from monetization. An alternative to this view is that the passage of the Gramm-Rudman-Hollings legislation in late 1985 signaled to the financial markets the prospect of significant deficit reduction by the end of the decade. According to this argument, the dollar depreciated because of the expectation of deficit reduction and a decline in government spending on domestic goods in the future, despite record budget deficits in the present.

A potential shortcoming with this argument is that the empirical results presented in Section 5 show a positive correlation between the current and long-run real exchange rate. Such a correlation is not consistent with the budget deficit account of the dollar's real appreciation if deficits were perceived to be transitory during the first half of the decade. In the simple theoretical model outlined in section 2, a transitory fiscal deficit - in the absence of offsetting increases in private saving - can be shown to result in a long-run real depreciation. This is because, in the absence of a permanent autonomous increase in demand for domestic goods, the export surplus required to service the outstanding stock of foreign debt accumulated during the 
current account adjustment process requires a long-run real depreciation which shifts foreign demand toward domestic goods which are in excess supply. This point is discussed in more detail in obstfeld (1985).

If budget deficits were perceived to be permanent in the early 1980's, this objection does not apply. The theoretical model outlined in Section 2 is too simple to be used to assess this possibility formally because it abstracts from economic growth, and thus the possibility of stabilizing the debt to output ratio in the context of a permanent fiscal deficit. Nevertheless, the budget deficit-real exchange rate link cannot be ruled out as one potential source of the dollar's real depreciation over the last two years.

The final major shift in U.S. policy since early 1985 is the enactment of the Tax Reform Act in 1986. According to estimates compiled by the Council of Economic Advisers (1987), tax reform, on net, will increase the cost of capital despite a lowering of the corporate tax rate, primarily because of the elimination of the investment tax credit. It has been argued that the surge in investment spending during the first three years of the current economic expansion and the appreciation of the dollar which occured through early 1985 were largely due to the increase in the after-tax profitability of investment resulting from the Economic Recovery Tax Act of 1981. The appreciation of the long-run real exchange rate during the first half of the decade is consistent with this view and the theoretical model model presented in Section 2. According to the logic of this argument, an increase in the cost of capital resulting from tax reform would be expected to reduce investment spending and depreciate both the current and long-run equilibrium level of the real exchange 
rate. Again this is consistent with the empirical results and the theoretical discussion.

The second implication of the results of this paper concerns the increase in real exchange rate volatility since the collapse of fixed exchange rates in the early 1970s. Mussa (1986) documents that, for pairs of countries with similar and moderate inflation rates, the real exchange rate typically shows much more short term volatility under floating rates than under fixed rates.

Mussa's interpretation of this result is that commitment to policies consistent with the maintenance of fixed nominal exchange rates plays a critical role in stabilizing the behavior of real exchange rates under the fixed-rate regime. According to this view, so long as agents believe that this commitment will be fulfilled, they need not worry about the implications of short-run variations in policy variables or other economic disturbances for the appropriate level of the nominal exchange rate. By contrast, under floating rates agents must continually revise their expectations of the future behavior of government policy in forming their expectations. The continual revision of expectations imparts to the nominal exchange rate its asset price properties. If national price levels respond less rapidly to new information than do nominal exchange rates, the volatility of the latter is transmitted to the real exchange rate.

The findings of this paper broaden our understanding of this result. For if real exchange rates are not only more volatile, but if their movements are largely expected to be permanent, then fluctuations in real exchange rates under a floating exchange rate regime are potentially more 
costly to private agents than would be the case if large fluctuations were rationally expected to be soon reversed. 


\section{$\underline{\text { References }}$}

Blanchard, $O$. and L. Summers, "Perspectives on High World Real Interest Rates," Brookings Papers on Economic Activity, 2:273-324, 1984.

Blinder, A., "The Policy Mix: Lessons from the Recent Past," Economic Outlook, 1:3-9, 1986 .

Branson. W., "Causes of Appreciation and Volatility of the Dollar," in The U.S. Dollar - Recent Developments, Outlook, and Policy Options, Kansas City: The Federal Reserve Bank of Kansas City, 1985.

Campbe11, J. and R. Clarida, "The Term Structure of Euromarket Interest Rates," Journal of Monetary Economics, 1987, forthcoming.

Clarida, R. and B. Friedman, "The Behavior of Short Term Interest Rates Since 1979", Journal of Finance, 39:671-682, 1984.

Council of Economic Advisers, Economic Report of the President, 1985 , 1986 and 1987 .

Cumby, R., "Is it Risk? Explaining Deviations from Interest Parity," New York University, Graduate School of Business Discussion Paper, 1985.

Cumby, R. and M. Obstfeld, "International Interest Rate and Price Level Linkages under Flexible Exchange Rates," in J. Bilson and R. Marston, eds., Exchange Rate Theory and Practice, Chicago: University of Chicago Press, 1984.

Dornbusch, R., "Expectations and Exchange Rate Dynamics," Journal of Political Economy, 84:1161-1176, 1976.

Fama, E., "Forward and Spot Exchange Rates," Journal of Monetary Economics, 14:319-338, 1984 .

Fama, E. and M. Gibbons, "Inflation, Real Returns, and Capital Investment," Journal of Monetary Economics, 9:297-323, 1982.

Frankel, J., "The Dazzling Dollar," Brookings Papers on Economic Activity, 1:199-217, 1985 .

Hamilton, J., "Uncovering Financial Market Expectations of Inflation," Journal of Political Economy, 93:1224-1241, 1985.

Hoey, R., "Decision Makers Pol1," Drexel Burnham Lambert, September 1986.

Huizinga, J., "An Empirical Investigation of the Long Run Behavior of Real Exchange Rates", Carnegie-Rochester Conference Series on Public Policy, 1987. 
Huizinga, J. and F. Mishkin, "Monetary Policy Regime Shifts and the Unusual Behavior of Real Interest Rates," Carnegie-Rochester Conference Series on Public Policy, 1985.

Mark, N., "Real and Nominal Exchange Rates in the Short Run and The Long Run," Department of Economics Working Paper, Ohio State University, July 1986.

Meese, R. and K. Rogoff, "Was it Real? The Exchange Rate-Interest Differential Relation, 1973-1984", National Bureau of Economic Research Working Paper No. 1732, 1985.

Mussa, M., "The Theory of Exchange Rate Determination," in J. Bilson and R. Marston, eds., Exchange Rate Theory and Practice, Chicago: University of Chicago Press, 1984.

Mussa, M., "Nominal Exchange Rate Regimes and the Behavior of Real Exchange Rates: Evidence and Implications", Carnegie-Rochester Conference Series on Public Policy, 1986.

Mussa, M. and J. Frenke1, "Asset Markets, Exchange Rates, and the Balance of Payments," in R. Jones and P. Kenen, eds., Handbook of International Economics Vo1. II, Amsterdam: North-Holland, 1985.

Obstfeld, M., "Floating Exchange Rates: Experience and Prospects," Brookings Papers on Economic Activity, 2:369-450, 1985.

Obstfeld, M., "Comment on Sachs," Brookings Papers on Economic Activity, $1: 190-195,1985$.

Poole, W., "Overview," in The U.S. Dollar - Recent Developments, Outlook, and Policy Options, Kansas City: The Federal Reserve Bank of Kansas City, 1985 .

Sachs, J., "The Dollar and the Policy Mix: 1985," Brookings Papers on Economic Activity, 1:117-197, 1985.

Shafer, J. and B. Loopesko, "Floating Exchange Rates After Ten Years," Brookings Papers on Economic Activity, 1:1-70, 1983. 
Table 1

Estimates of Real Long-Term Interest Differentials - February 1985

\begin{tabular}{|c|c|c|c|}
\hline Item & U.S. & $\begin{array}{l}\text { Weighted - average of } \\
\text { other G7 countries }\end{array}$ & Differential \\
\hline \multicolumn{4}{|l|}{ Long-term } \\
\hline govt. bond rate & 11.70 & 9.33 & -2.37 \\
\hline $\begin{array}{l}\text { one-year lagged } \\
\text { inflation }\end{array}$ & 3.54 & 4.07 & \\
\hline est. real rate & 8.16 & 5.25 & -2.90 \\
\hline $\begin{array}{l}\text { distrib. lag of } \\
\text { inflation }\end{array}$ & 3.83 & 4.92 & \\
\hline est. real rate & 7.87 & 4.41 & -3.46 \\
\hline $\begin{array}{l}\text { DRI forecast } \\
\text { inflation }\end{array}$ & 4.16 & 4.49 & \\
\hline est. real rate & 7.54 & 4.84 & -2.70 \\
\hline $\begin{array}{l}\text { Hoey survey of } \\
\text { inflation }\end{array}$ & 5.49 & & \\
\hline est. real rate & 6.21 & $5.25 *$ & $-0.96 *$ \\
\hline
\end{tabular}

Al1 but the last two rows of table are from Frankel (1985), p. 200. The survey of ten year U.S. inflation expectations are from Hoey (1986).

* Frankel's maximum estimate of the average long-term real rate in the other 67 countries. Thus the difference between the U.S. real rate implied by Hoey's survey, 6.21, and Frankel's maximum average foreign rate, 5.25, gives a lower bound of 0.96 on the absolute value of the real differential in February 1985. 
Table 2

Summary Statistics, 1979:10-1986:3

Statistic

Country

Canada U.K. Germany Japan $\begin{gathered}\text { Trade-Weighted } \\ \text { Average }\end{gathered}$

Mean

change in real

exchange rate

$\begin{array}{lllll}-1.380 & -3.823 & -5.200 & 1.542 & -1.335\end{array}$

Standard

deviation of

change in real

exchange rate

$15.197 \quad 44.909$

$42.783 \quad 43.954$

23.139

Mean real

interest

differential

$-0.890$

$-1.233$

$-2.390$

$-1.793$

$-1.381$

Standard

deviation of

ex post real

interest

differential

7.503

3.609

8.167

3.592

Correlation of change in real exchange rate and

ex post real

interest

differential

$-0.191-0.172$

0.004

$-0.112$

$-0.069$

Autocorrelations

of ex post real

interest

differential:

1

2

3

4

5

6
0.165

0.251

0.657

0.034

0.329

$-0.105$

0.034

0.388

$-0.169$

0.111

$0.028 \quad 0.052$

0.233

$-0.123$

$-0.001$

$0.144 \quad-0.054$

0.075

0.133

0.035

0.035

0.033

0.165

0.174

0.278

$-0.047 \quad 0.036$

0.278

0.176

0.353 
Table 3

Real Interest Differentials and Exchange Rates - Canada 1979:10-1986:3

Uncovered interest parity model:

Log likelihood 544.33

Parameters $\alpha \quad 1.00$ (fixed)

$\rho \quad 0.35(0.45)$

$\lambda \quad-0.10(0.31)$

$\begin{array}{rr}\sigma_{1} & 2.85 \\ \sigma_{2} & 3.34 \\ \sigma_{3} & 13.64 \\ \sigma_{13} / \sigma_{1} \sigma_{3} & 0.11\end{array}$

Variance decomposition for ex post real interest differential: Ex ante real interest differential 45.78 Inflation innovations $\quad 54.38$

Variance decomposition for real exchange rate innovations:

Innovations in ex ante real interest differential 9.08 Innovations in long-run equilibrium exchange rate 84.78 Covariance 6.38

Correlation between innovations in:

Real exchange rate and ex ante differential $\quad 0.40$

Real exchange rate and long-run equilibrium rate 0.95

$\begin{array}{ll}\text { Ex ante differential and long-run equilibrium rate } & 0.11\end{array}$

\section{Linear risk premium model:}

Log likelihood 544.37

Parameters $\alpha \quad 1.61(1.57)$

$\rho \quad 0.35(0.45)$

$\lambda \quad-0.04(0.20)$

$\sigma_{1} \quad 2.35$

$\sigma_{2}^{1} \quad 3.77$

$\sigma_{3}^{2} 12.64$

$\begin{array}{rr}\sigma_{13} / \sigma_{1} \sigma_{3} & 0.13\end{array}$

Variance decomposition for ex post real interest differential: $\begin{array}{ll}\text { Ex ante real interest differential } & 30.8 \%\end{array}$ Inflation innovations 69.28

Variance decomposition for real exchange rate innovations: Innovations in ex ante real interest differential 15.98 Innovations in long-run equilibrium exchange rate 75.18 $\begin{array}{ll}\text { Covariance } & 8.98\end{array}$

Correlation between innovations in:

$\begin{array}{ll}\text { Real exchange rate and ex ante differential } & 0.51\end{array}$

Real exchange rate and long-run equilibrium rate $\quad 0.92$

Ex ante differential and long-run equilibrium rate 0.13 
Table 4

Real Interest Differentials and Exchange Rates - U.K. 1979:10-1986:3

Uncovered interest parity model:

$\begin{array}{rrl}\text { Log likelihood } & 425.25 \\ \text { Parameters } \alpha & 1.00 \text { (fixed) } \\ \rho & 0.69(0.22) \\ \lambda & -0.49 & (0.65) \\ \sigma_{1} & 2.74 \\ \sigma_{2} & 5.33 \\ \sigma_{3} & 40.03 \\ \sigma_{13} / \sigma_{1} \sigma_{3} & 0.37\end{array}$

Variance decomposition for ex post real interest differential: Ex ante real interest differential 49.18 Inflation innovations 50.98

Variance decomposition for real exchange rate innovations: Innovations in ex ante real interest differential 7.58 Innovations in long-run equilibrium exchange rate 79.38 Covariance

Correlation between innovations in:

Real exchange rate and ex ante differential 0.52

Real exchange rate and long-run equilibrium rate 0.96

Ex ante differential and long-run equilibrium rate 0.27

\section{Linear risk premium model:}

Log likelihood 426.39

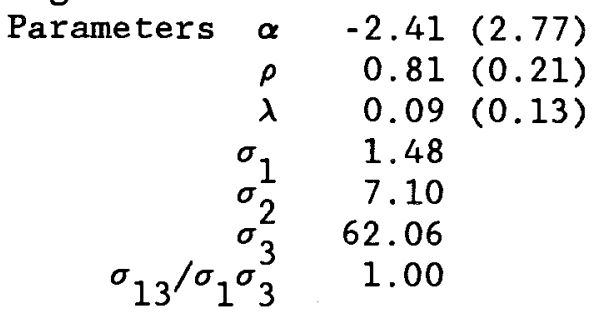

Variance decomposition for ex post real interest differential:

Ex ante real interest differential 13.18

Inflation innovations $\quad 86.98$

Variance decomposition for real exchange rate innovations:

Innovations in ex ante real interest differential 21.48

Innovations in long-run equilibrium exchange rate 197.88

Covariance

$-119.28$

Correlation between innovations in:

Real exchange rate and ex ante differential 0.83

Real exchange rate and long-run equilibrium rate $\quad 0.98$

$\begin{array}{ll}\text { Ex ante differential and long-run equilibrium rate } & 0.92\end{array}$ 
Table 5

Real Interest Differentials and Exchange Rates - Germany 1979:10-1986:3

\section{Uncovered interest parity model:}

Log likelihood 488.52

Parameters $\alpha \quad 1.00$ (fixed)

$\rho \quad 0.58(0.12)$

$\lambda \quad 8.48(* * * *)$

$\begin{array}{rr}\sigma_{1} & 0.26 \\ \sigma_{2} & 0.40 \\ \sigma_{3} & 42.92 \\ \sigma_{13} / \sigma_{1} \sigma_{3} & -0.59\end{array}$

Variance decomposition for ex post real interest differential: Ex ante real interest differential $99.1 \%$ Inflation innovations $0.9 \%$

Variance decomposition for real exchange rate innovations: Innovations in ex ante real interest differential $3.5 \%$ Innovations in long-run equilibrium exchange rate 98.28 Covariance

Correlation between innovations in:

Real exchange rate and ex ante differential 0.14

Real exchange rate and long-run equilibrium rate $\quad 0.98$

Ex ante differential and long-run equilibrium rate $\quad-0.04$

\section{Linear risk premium model:}

Log likelihood 491.49

$\begin{array}{rrr}\text { Parameters } \alpha & -3.26 & (1.61) \\ \rho & 0.51 & (0.15) \\ \lambda & 1.07 & (0.53) \\ \sigma_{1} & 2.21 & \\ \sigma_{2} & 2.13 & \\ \sigma_{3} & 46.07 & \\ \sigma_{13} / \sigma_{1} \sigma_{3} & 0.65 & \end{array}$

Variance decomposition for ex post real interest differential: Ex ante real interest differential 75.08 Inflation innovations $25.0 \%$

Variance decomposition for real exchange rate innovations: Innovations in ex ante real interest differential 26.78 Innovations in long-run equilibrium exchange rate 125.98 Covariance

Correlation between innovations in:

Real exchange rate and ex ante differential $\quad-0.01$

Real exchange rate and long-run equilibrium rate $\quad 0.89$

Ex ante differential and long-run equilibrium rate 0.45 
Table 6

Real Interest Differentials and Exchange Rates - Japan 1979:10-1986:3

Uncovered interest parity model:

$\begin{array}{rrl}\text { Log likelihood } & 415.98 & \\ \text { Parameters } \alpha & 1.00 \text { (fixed) } \\ \rho & 0.73(0.34) \\ \lambda & -0.18 & (0.29) \\ \sigma_{1} & 1.94 & \\ \sigma_{2} & 7.58 & \\ \sigma_{3} & 39.41 & \\ \sigma_{13} / \sigma_{1} \sigma_{3} & 0.50 & \end{array}$

Variance decomposition for ex post real interest differential: Ex ante real interest differential 17.38 Inflation innovations $82.7 \%$

Variance decomposition for real exchange rate innovations: Innovations in ex ante real interest differential 4.08 Innovations in long-run equilibrium exchange rate 81.18 $\begin{array}{ll}\text { Covariance } & 14.88\end{array}$

Correlation between innovations in:

$\begin{array}{ll}\text { Real exchange rate and ex ante differential } & 0.57\end{array}$

Real exchange rate and long-run equilibrium rate 0.98

Ex ante differential and long-run equilibrium rate $\quad 0.41$

Linear risk premium model:

Log likelihood 416.14

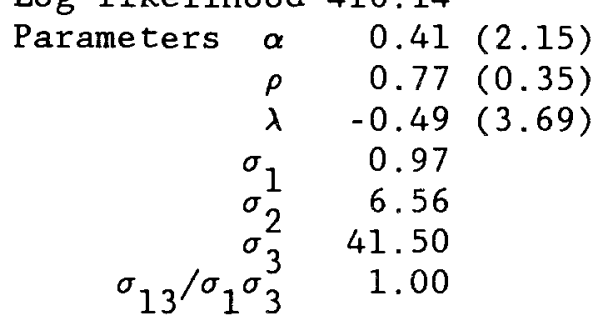

Variance decomposition for ex post real interest differential: Ex ante real interest differential 38.38 Inflation innovations $\quad 61.78$

Variance decomposition for real exchange rate innovations: Innovations in ex ante real interest differential 1.88 Innovations in long-run equilibrium exchange rate 90.88 Covariance $\quad 7.48$

Correlation between innovations in:

Real exchange rate and ex ante differential 0.41

Real exchange rate and long-run equilibrium rate 0.99

Ex ante differential and long-run equilibrium rate 0.29 
Table 7

Real Interest Differentials and Exchange Rates - Trade Weighted Average $1979: 10-1986: 3$

Uncovered interest parity model:

Log likelihood 527.31

$\begin{array}{rrl}\text { Parameters } & \alpha & 1.00 \text { (fixed) } \\ \rho & 0.66 & (0.23) \\ \lambda & -0.18 & (0.45) \\ \sigma & 1.80 & \\ \sigma_{1} & 2.79 & \\ \sigma_{3}^{2} & 21.27 & \\ \sigma_{13} / \sigma_{1} \sigma_{3} & 0.24 & \end{array}$

Variance decomposition for ex post real interest differential: Ex ante real interest differential 44.38 Inflation innovations 55.78

Variance decomposition for real exchange rate innovations:

Innovations in ex ante real interest differential 5.68

Innovations in long-run equilibrium exchange rate 84.28

$\begin{array}{ll}\text { Covariance } & 10.28\end{array}$

Correlation between innovations in:

Real exchange rate and ex ante differential $\quad 0.45$

Real exchange rate and long-run equilibrium rate $\quad 0.97$

Ex ante differential and long-run equilibrium rate 0.23

Linear risk premium model:

Log likelihood 529.23

Parameters $\alpha \quad-2.72(1.74)$

$\rho \quad 0.79(0.20)$

$\begin{array}{rrr}\lambda & 0.09 & (0.12) \\ \sigma_{1} & 1.09 & \\ \sigma_{2} & 3.33 \\ \sigma_{3} & 30.73 & \\ \sigma_{13} / \sigma_{1} \sigma_{3} & 0.76\end{array}$

Variance decomposition for ex post real interest differential:

Ex ante real interest differential 23.38

Inflation innovations 76.78

Variance decomposition for real exchange rate innovations:

Innovations in ex ante real interest differential 42.28

Innovations in long-run equilibrium exchange rate 187.68

Covariance $\quad-129.78$

Correlation between innovations in:

Real exchange rate and ex ante differential 0.35

Real exchange rate and long-run equilibrium rate $\quad 0.90$

Ex ante differential and long-run equilibrium rate 0.73 